NBER WORKING PAPER SERIES

\title{
THE TROUBLE WITH STOCK OPTIONS
}

\author{
Brian J. Hall \\ Kevin J. Murphy \\ Working Paper 9784 \\ http://www.nber.org/papers/w9784 \\ NATIONAL BUREAU OF ECONOMIC RESEARCH \\ 1050 Massachusetts Avenue \\ Cambridge, MA 02138 \\ June 2003
}

We are grateful for research support from the Division of Research at Harvard Business School (Hall) and USC's Marshall School (Murphy). We thank Harry DeAngelo, Linda DeAngelo, Bradford DeLong, Michael Waldman, Paul Oyer, Tim Taylor, Jan Zábojník and Aaron Zimmerman for helpful comments. The views expressed herein are those of the authors and not necessarily those of the National Bureau of Economic Research.

(C2003 by Brian J. Hall and Kevin J. Murphy. All rights reserved. Short sections of text not to exceed two paragraphs, may be quoted without explicit permission provided that full credit including (C) notice, is given to the source. 
The Trouble with Stock Options

Brian J. Hall and Kevin J. Murphy

NBER Working Paper No. 9784

June 2003

JEL No. J0, J3, G3, L0, L2

\section{$\underline{\text { ABSTRACT }}$}

The trouble with options is that too many options are granted to too many people. Most options are granted below the top-executive level, and options are often an inefficient way to attract, retain and motivate executives and (especially) lower-level employees. Why, then, are options so prevalent? We discuss several explanations including changes in corporate governance, reporting requirements, taxes, the bull market and managerial rent-seeking. We also offer an alternative hypothesis that we believe explains the over-use of options and several apparent puzzles: boards and managers falsely perceive stock options to be inexpensive because of accounting and cash-flow considerations.

Brian J. Hall

Harvard Business School

Baker Library 185

Boston, MA 02163

and NBER

bhall@hbs.edu
Kevin J. Murphy

Marshall School of Business

University of Southern California

kjmurphy@usc.edu 


\title{
The Trouble with Stock Options
}

\author{
Brian J. Hall and Kevin J. Murphy
}

The most pronounced change in corporate compensation practices over the past decade is the escalation and recent decline in executive and employee stock options. In 1992, firms in the Standard \& Poor's 500 granted their employees options worth a total of $\$ 11$ billion at the time of grant; by 2000, option grants in S\&P 500 firms increased to $\$ 119$ billion. ${ }^{1}$ By 2002 , option grants in the S\&P 500 had fallen to $\$ 71$ billion, well below their peak but still a six-fold increase from a decade earlier. Despite—or perhaps because of - their growing importance, employee stock options have become increasingly controversial.

The main argument in favor of stock option plans is that they give executives a greater incentive to act in the interests of shareholders by providing a direct link between realized compensation and company stock-price performance. In addition, offering employee stock options in lieu of cash compensation allows companies to attract highly motivated and entrepreneurial employees, and also lets companies obtain employment services without (directly) expending cash. Options are typically structured so that only employees who remain with the firm can benefit from them, thus also providing retention incentives. Finally, stock options encourage executive risk taking, which can mitigate problems with executive risk aversion.

Option values are in 2002-constant dollars and are based on Compustat's ExecuComp data; see Figure 1 below for calculation details. Data are not available for all S\&P 500 firms; the total for S\&P 500 firms is estimated as 500 times the average grant for S\&P 500 firms with available data. 
But the incentives provided by stock options have also been criticized. The recent accounting scandals at Enron, WorldCom, Global Crossing and other companies, have been linked to excessive risk taking and an excessive fixation on stock prices, both allegedly caused by the escalation in option grants (Cassidy, 2002; Madrick, 2003). Moreover, these scandals have focused attention on problems with current accounting practices, which in turn has opened a debate on the accounting treatment of employee stock options. Under current U.S. accounting rules, companies generally do not treat options as an expense on company financial statements. Proponents of expensing options argue that expensing will generate more informative financial statements and improve the credibility of reported earnings. Opponents of expensing worry that expensing will cause companies to grant fewer options, especially to lower-level employees, which in turn will "destroy the engine that fueled the economic growth" of the 1990s.

In this article, we explore the trouble with stock options. We begin by describing patterns in employee options since the early 1990s and by describing the relevant tax and accounting rules; we later argue that these rules help explain the widespread use of optionbased pay. Next, we analyze the efficiency of providing compensation and incentives using stock options, focusing on the fact that risk-averse and undiversified employees will value options significantly less than they cost the company to grant. We identify several problems with options granted to top executives and even more problems with options granted to lower-level employees. These conclusions deepen the question of why grants of options have increased so dramatically, especially among rank-and-file workers. We consider several explanations for the recent trends in option practices, including changes in corporate governance and tax laws, managerial influence over their own pay packages, the bull market 
in equities of the 1990s and our preferred hypothesis that the perceived cost of options to boards and managers is lower than the actual economic cost of granting such options.

\section{A Brief Primer on Stock Options}

Employee stock options are contracts that give the employee the right to buy a share of stock at a pre-specified "exercise" price for a pre-specified term. Most employee stock options expire in ten years and are granted with an exercise price equal to the market price on the date of grant. Typically a grant of stock options cannot be exercised immediately, but only over time; for example, 25 percent might become exercisable in each of the four years following grant. When a stock option can be exercised, then the option is said to be "vested." Employee options are non-tradable, and are typically forfeited if the employee leaves the firm before vesting (although "accelerated vesting" is a commonly negotiated severance benefit for top-level executives, especially following a change in control).

When an employee exercises an option, the company typically issues a new share, which increases the number of shares outstanding. Although some companies require employees to pay exercise prices in cash, most companies offer "cashless exercise programs," where the employee pays nothing and simply receives the value of the spread between the market price and the exercise price either in cash or in shares of company stock.

\section{Trends in Stock Options Since the Early 1990s}

Figure 1 shows the average inflation-adjusted grant-date values of options granted by the average firm in the S\&P 500 from 1992-2002. Over this decade, the value of options granted increased from an average of \$22 million per company to \$238 million per company 
by 2000 , falling to $\$ 141$ million per company in 2002 . Although the exact percentages have varied from year to year, the chief executive officer's (CEO's) share of the total grant has fallen from about seven percent of the total in the mid-1990s to under five percent in 20002002. Managers and employees below the five top executives have received an increasing share of the total grant: grants to this group have grown from less than 85 percent of the total in the mid-1990s to over 90 percent by 2002 .

The average real pay for S\&P 500 CEOs skyrocketed during the 1990s, growing from \$3.5 million in 1992 to $\$ 14.7$ million in 2000. Most of this increase reflects the escalation in stock options valued at time of grant, which grew nine-fold from an average of about $\$ 800,000$ in 1992 to nearly $\$ 7.2$ million in 2000. (In contrast, other components of total compensation merely tripled during this period.) Average real CEO pay in the S\&P 500 tumbled to only $\$ 9.4$ million in 2002 , driven by a 40 percent two-year drop in the value of options granted. 
Figure 1

Grant-Date Values of Employee Stock Options in the S\&P 500, 1992-2002

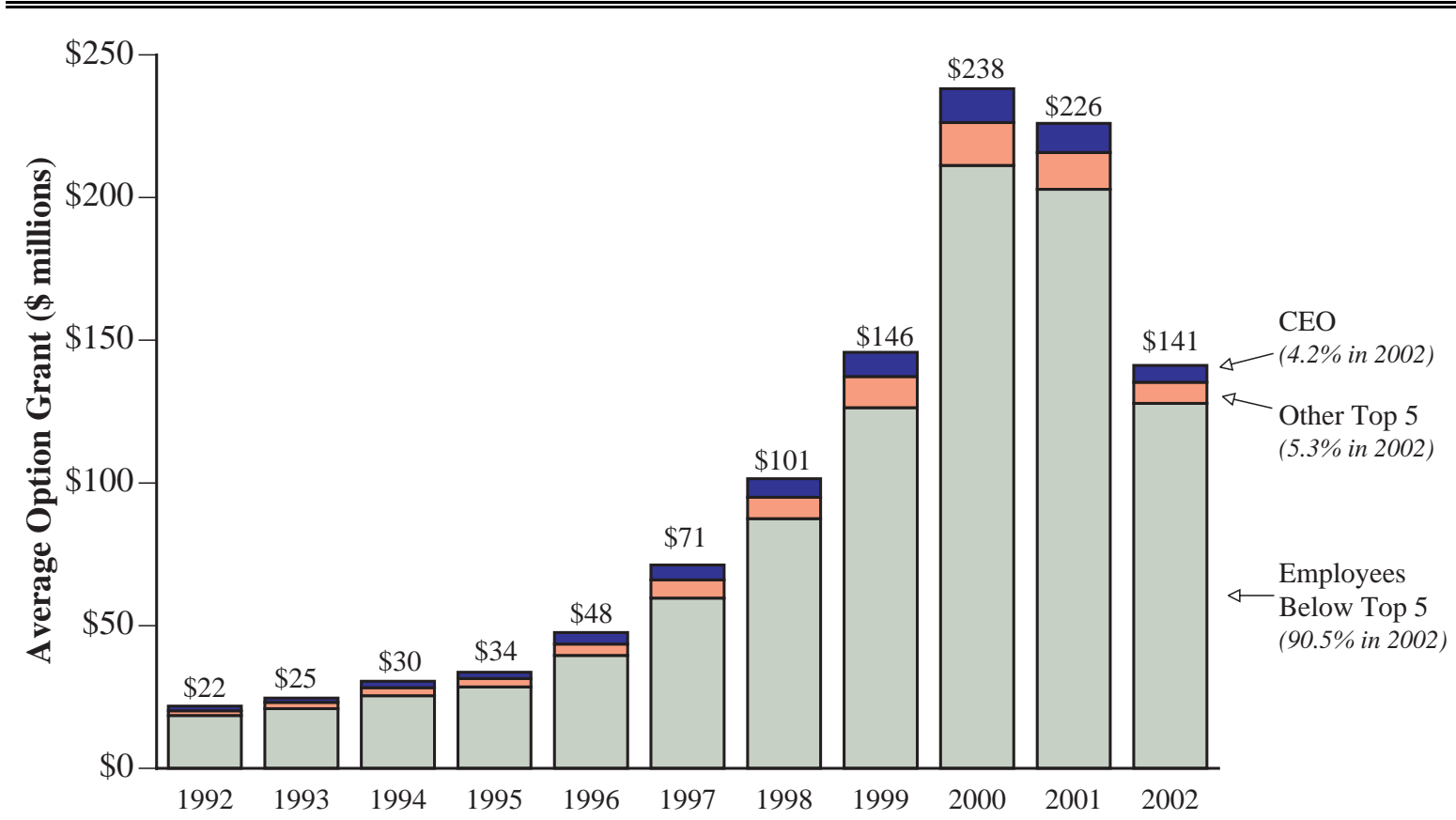

Note: Figure shows the grant-date value of options (in millions of 2002-constant dollars) granted to all employees in an average S\&P 500 firm, based on data from S\&P's ExecuComp data. Grants below the Top 5 are estimated based on "Percent of Total Grant" disclosures; companies not granting options to any of their top five executives are excluded. Grant-values are based on ExecuComp's Black-Scholes calculations. The number in parentheses indicates the fraction of the grant, on average, that is awarded to the indicated employee (or employee group). Fiscal 2002 results are based on the April 2003 "cut" of ExecuComp, which includes only companies with fiscal closings in December 2002 or earlier.

The escalation in CEO pay during the 1990s is well known and highly scrutinized. Less well recognized, but evident from Figure 1, is the fact that the escalation in option grants was not restricted to CEOs or even to top-level executives. The increase in employee stock options has occurred across a wide range of industries, but is especially pronounced in the so-called "new economy" firms related to computers, software, the Internet, telecommunications or networking. The first four columns of Table 1 show option grants as a percent of company stock for four industry groups and for companies in the S\&P 500, S\&P MidCap 400 (Standard \& Poor's "representative" portfolio of 400 mid-size firms) and S\&P SmallCap 600 (Standard \& Poor's representative portfolio of 600 smaller firms). Between 
Table 1

Option Grants as a Percent of Outstanding Shares and as Value per Employee, by Industry, 1993-2001

\begin{tabular}{|c|c|c|c|c|c|c|c|c|}
\hline \multirow[b]{2}{*}{$\begin{array}{l}\text { Fiscal } \\
\text { Year }\end{array}$} & \multicolumn{4}{|c|}{$\begin{array}{l}\text { Panel A. Percent of Outstanding Shares } \\
\text { Granted in Options in Each Year }\end{array}$} & \multicolumn{4}{|c|}{$\begin{array}{l}\text { Panel B. Average Grant-Date Value of } \\
\text { Options per Employee (below top 5) for all } \\
\text { Employees in Industry }\end{array}$} \\
\hline & $\begin{array}{c}\text { Old } \\
\text { Economy }\end{array}$ & $\begin{array}{l}\text { New } \\
\text { Economy }\end{array}$ & Finance & Utilities & $\begin{array}{c}\text { Old } \\
\text { Economy }\end{array}$ & $\begin{array}{l}\text { New } \\
\text { Economy }\end{array}$ & Finance & Utilities \\
\hline 1993 & $1.8 \%$ & $4.2 \%$ & $1.7 \%$ & $0.9 \%$ & $\$ 522$ & $\$ 1,684$ & $\$ 1,007$ & $\$ 271$ \\
\hline 1994 & $1.8 \%$ & $4.2 \%$ & $1.9 \%$ & $0.9 \%$ & $\$ 633$ & $\$ 1,855$ & $\$ 1,570$ & $\$ 383$ \\
\hline 1995 & $1.9 \%$ & $4.3 \%$ & $1.8 \%$ & $0.9 \%$ & $\$ 655$ & $\$ 2,533$ & $\$ 1,310$ & $\$ 388$ \\
\hline 1996 & $2.1 \%$ & $5.2 \%$ & $2.0 \%$ & $1.0 \%$ & $\$ 904$ & $\$ 3,834$ & $\$ 2,005$ & $\$ 690$ \\
\hline 1997 & $2.3 \%$ & $6.4 \%$ & $2.3 \%$ & $0.9 \%$ & $\$ 1,162$ & $\$ 6,021$ & $\$ 3,365$ & $\$ 518$ \\
\hline 1998 & $2.7 \%$ & $7.1 \%$ & $2.5 \%$ & $1.2 \%$ & $\$ 1,376$ & $\$ 7,334$ & $\$ 5,060$ & $\$ 649$ \\
\hline 1999 & $2.8 \%$ & $6.6 \%$ & $2.2 \%$ & $1.5 \%$ & $\$ 2,169$ & $\$ 11,838$ & $\$ 5,259$ & $\$ 1,797$ \\
\hline 2000 & $2.9 \%$ & $7.4 \%$ & $2.4 \%$ & $1.5 \%$ & $\$ 2,559$ & $\$ 26,690$ & $\$ 4,806$ & $\$ 1,385$ \\
\hline 2001 & $2.6 \%$ & $6.4 \%$ & $2.5 \%$ & $1.4 \%$ & $\$ 2,856$ & $\$ 18,882$ & $\$ 5,562$ & $\$ 2,933$ \\
\hline
\end{tabular}

Note: Data from Compustat's ExecuComp database, and includes data from firms in the S\&P 500, the S\&P Mid-Cap 400, and the S\&P SmallCap 600. New economy firms defined as companies with primary SIC codes 3570, 3571, $3572,3576,3577,3661,3674,4812$, 4813, 5045, 5961, 7370, 7371, 7372 and 7373. Old economy firms are firms with SIC codes less than 4000 not otherwise categorized as new economy. Financial services firms have two-digit SIC codes between 60 and 69; utilities have two-digit SIC code of 49. Utilities option values based on average value of options granted to Top 5 executives, using ExecuComp's modified Black-Scholes methodology.

1993 and their peak in 2000, grants in "old economy" firms increased 44 percent from 1.8 percent of outstanding shares to 2.9 percent, while grants in new economy increased 75 percent from 4.2 percent to 7.4 percent; grants in financial services firms and utilities increased by about 50 percent.

The second four columns of Table 1 shows the inflation-adjusted dollar-value of grants per employee in four industries, excluding grants made to each company's five top executives. ${ }^{2}$ Grant-values for the average employee in old economy firms increased from

2 The average grant value is determined by dividing the total value of grants in each industry (in 2002constant dollars, after excluding grants to the top five executives) by the total number of employees in the industry. Companies not granting options to their top five executives are excluded from this analysis. 
$\$ 522$ in 1993 to nearly $\$ 2,900$ in 2001, while grant-values increased from $\$ 1,684$ to nearly $\$ 19,000$ per employee in new economy firms. At their peak in 2000, the average employee in a new economy company received options worth nearly $\$ 27,000$.

The data in Figure 1 and Table 1 do not quite reveal the increased prevalence of "broad-based" option plans that cover all or most company employees, because the group "below the top five" includes senior executives as well as the rank and file. However, according to the National Center on Employee Ownership (NCEO), between seven and ten million employees in U.S. firms held options in 2000, compared to only one million in 1992. Oyer and Schaefer (2002) estimate that options are distributed to more than half of employees in 43 percent of all public firms (but this covers only about six percent of publicfirm employees, since smaller companies are more likely to offer options to a broader base).

\section{Tax Rules Affecting Stock Options}

Although economists have generally focused on the incentive aspects of employee options, the popularity of stock options reflects in large part their favorable tax and accounting treatments, which we believe are critical in understanding why, how and to whom options are granted.

Under U.S. tax rules, the granting of a stock option does not constitute a taxable event for either the company or the employee. What happens later depends on whether the options are "qualified" (called Incentive Stock Options or ISOs) or "non-qualified." For nonqualified options, the spread between the market and exercise price upon exercise constitutes taxable personal income to the employee, and a compensation-expense deduction for the company. For qualified options, the employee pays nothing upon exercise, and pays capital 
gains taxes when eventually selling the stock; the corporation, however, cannot deduct the gain on a qualified option as a compensation expense. As a result of this loss of deductibility, combined with the fact that that qualified options involve holding requirements (recipients must hold the stock for at least one year after exercise) and other limits and restrictions, most employee option grants are non-qualified.

Tax laws enacted in 1994 indirectly affected option-granting practices. Under Section 162(m) of the Internal Revenue Code, compensation in excess of $\$ 1$ million paid to "proxynamed executives" (typically the company's five highest-paid officers) is considered unreasonable and no longer deductible as a corporate compensation expense. However, Section 162(m) does not impose limitations on "performance-based" compensation, including payments from exercising options. This new law made stock options relatively less expensive than, say, base salaries or stock grants, and may therefore help to explain the explosion in executive option grants in the 1990s.

\section{Option "Accounting"}

Corporations in the United States keep two separate ledgers of revenues and expenses, one for tax purposes and one for accounting purposes. Although gains from exercising nonqualified options are treated as an expense for tax purposes, there is usually no accounting expense recorded for options either at time of grant or exercise.

The accounting rules governing employee stock options are established by the Financial Accounting Standards Board (FASB) and its predecessor, the Accounting Principles Board (APB). Under APB Opinion 25, issued in 1972, the accounting charge for stock options equals the difference between the market price of the stock and the exercise 
price on the date that both the exercise price and the number of options becomes known or fixed. There is no charge for options granted with an exercise price equal to (or exceeding) the grant-date market price, because the spread is zero on the grant date. Notice that this rule would impose a higher accounting charge for options with an exercise price indexed to the market, because the exercise price is not immediately fixed. It would also imposed a higher accounting charge for options that only become exercisable if certain performance triggers are achieved, because the number of options is not immediately fixed.

In 1995, FASB issued FAS 123, which recommended that companies expense the "fair market value" of options granted (using Black-Scholes or a similar valuation methodology). However, FASB also allowed firms to continue reporting under APB Opinion 25, with the additional requirement that the value of the option grant would be disclosed in a footnote to the financial statements. Until late 2002, only a handful of companies adopted FASB's recommended approach. However, by early 2003, following several accounting scandals that focused attention on accounting problems, more than 100 companies had voluntarily begun to expense options.

Companies with declining stock prices have routinely "repriced" their existing employee stock options, either by resetting the exercise price or (equivalently) by replacing old options with new options with a lower exercise price. In December 1998, FASB imposed "variable accounting" (where the accounting charge adjusts over the vesting period based on realized stock prices) for companies repricing their options. 


\section{Are Options Efficient?}

With few exceptions, the theoretical and empirical research on employee stock options treat options as part of an optimal incentive arrangement that mitigates agency problems between shareholders and self-interested managers by tying pay directly to stock-price appreciation. But most options are granted to employees well below the top-executive level, and many firms offer options to all employees. Given the increasing prevalence of broadbased plans, a compelling theory of employee stock options must explain not only executive stock options but also options granted to the rank and file.

Are options, as typically structured, the most efficient way to attract, retain and motivate top-level executives whose actions directly affect stock prices? And, are options plausibly an efficient way of attracting, retaining and motivating workers whose influence on stock prices is difficult to quantify or detect? Answering these questions requires considering the distinction between the cost of options to the firm and the value of options to executives and employees, and analyzing the incentives that stock options provide for both top managers and the rank and file.

\section{The Gap Between Cost and Value of Stock Options}

The cost to a firm of granting a stock option is larger than the value of the stock option to the employee receiving it. The economic or "opportunity" cost of an option to a firm can be conceived in several ways. For example, the cost of options to shareholders is the amount the company would have to pay an outside investor to accept the financial liability of options granted to employees. Equivalently, the cost of options is the amount an outside investor would pay for the option, assuming that the outside investor faced the same exercise and 
forfeiture patterns of company employees. After downward adjustments for potential forfeiture and early exercise, standard methodologies such as Black-Scholes (1973) or binomial option pricing formulas provide reasonable estimates of what an outside investor would pay, and therefore measure the company's cost of granting options. ${ }^{3}$

However, these standard models are not appropriate for determining the value of options held by undiversified, risk-averse employees who can not freely sell or trade the options nor hedge their risk through short-selling or other methods. In other words, employees should have a clear preference for compensation in cash or in a diversified portfolio of stocks rather than receiving an equal value of nontradable and undiversified stock options. The idea that options cost companies more than they are worth to employeerecipients is not surprising: it stems from the basic concept that individuals demand compensating differentials for bearing risk. Indeed, if employees valued options at their cost to the company, then employees should be paid entirely in options rather than cash as long as options offer any positive incentive benefits.

Press accounts sometimes claim that executives can effectively hedge or unwind the risk of their options through financial transactions (involving derivatives) with investment banks. But we know of no evidence showing that this practice is widespread, and our many conversations with knowledgeable practitioners suggest that this practice is quite rare. Although executives sometimes hedge the risk of their unrestricted stock holdings, it is more difficult to hedge option risk because executives are legally precluded from shorting their company stock, trading their options or "restricted stock" (stock that cannot be freely sold by

3 Binomial models can more accurately measure the company cost of options than the Black-Scholes formula because the binominal approach can more flexibly take into account expected forfeitures and early 
the executives), or pledging these securities as collateral. Moreover, Schizer (2000) documents that significant tax disadvantages would result from hedging restricted stock or options. Finally, even if some top executives have hedged some of their option holdings, such schemes are not available to lower-level managers and employees who receive 90 percent of stock options granted.

In Hall and Murphy (2000, 2002), we compare the company's cost of granting employee stock options to the value of the same stock options to employees using a certainty-equivalence approach. ${ }^{4}$ For reasonable assumptions about risk aversion and diversification, we find that employees value options that have just been granted with an exercise price equal to the market price at only about half of their cost to the firm. This value:cost ratio is substantially smaller if the options have an exercise price that is above the existing market price, or if the exercise prices increases over time, or if the option has a long vesting period.

Thus, in determining whether stock options are an efficient method of providing compensation, the question hinges on whether the attraction, retention and motivational benefits of options are sufficient to justify the large compensating differential implied by the wedge between the cost and value of options.

\section{Attraction?}

A potential benefit of providing compensation in the form of options is that the company can attract employees without spending cash. However, this benefit must be 
weighed against the compensating differential demanded by option-holding employees. Companies paying options in lieu of cash are effectively borrowing from employees, receiving employment services today in return for highly variable (and often non-existent) payouts in the future. But risk-averse undiversified employees are unlikely to be efficient sources of capital, especially compared to banks, private equity funds, venture capitalists and other investors who specialize in managing risk and providing capital.

The empirical evidence that companies grant options to conserve cash is mixed. Core and Guay (2001) find greater use of employee options in firms facing financial constraints. However, in a study of new economy firms, Ittner, Lambert and Larcker (2003) find that companies with greater cash flows use options more extensively. Indeed, option-intensive companies like Microsoft, Intel and Cisco are well known for paying cash compensation above competitive levels, and Microsoft and others routinely use their excess cash to repurchase shares to reduce the dilution caused by large option grants.

The euphoria surrounding the bull market of the late 1990s led many employees to clamor for stock options, which might suggest that companies could attract workers by offering options while reducing other components of compensation. But, "clamoring" does not obviously translate into willingness to pay: most broad-based option plans are added on top of existing competitive pay packages. As shown in Table 1, the average employee in a new economy firm received options costing shareholders almost $\$ 27,000$ in 2000 . It is not surprising that employees clamor for such options when they are largely add-ons. But since employees are unwilling to pay close to the full cost of their options, broad-based options are

$4 \quad$ See also Lambert, Larcker and Verrechia (1991). Meulbroek (2001) uses a non-utility-based approach to distinguish between cost and value, and obtains similar results. 
an inefficient substitute for cash compensation and therefore an inefficient way to attract employees.

Paying options in lieu of cash compensation will affect the type of employees the company can attract. For example, highly motivated and entrepreneurial employees who believe they can increase company stock prices will be attracted to companies offering relatively more option-based compensation. Whether this benefit justifies the compensating differential "charged" by employees for accepting risky compensation depends on the strength and value of this sorting and on the availability of other (less costly) measures of managerial characteristics. In any case, this rationale for stock options as an attraction device is limited to top managers and perhaps to some key engineering or technical employees who can directly affect company stock prices, and these individuals account for a small fraction of the option grants.

For lower-level positions in the corporate hierarchy, paying options in lieu of cash compensation will attract employees who are relatively less risk-averse. However, if attracting less risk-averse employees is an important objective, offering bonus plans tied to performance measures in the employee's "line of sight" can provide both sorting and incentives, while payments to lower-level workers based on stock prices will provide sorting but not incentives.

In summary, it is difficult to justify using options to achieve objectives related to attraction. At best, paying in stock options may help the company attract entrepreneurial top managers or some key engineering or technical employees, but it is difficult to tell a compelling story about the benefits of using stock options to attract lower-level employees. 


\section{Retention?}

Employee stock options provide retention incentives through restrictions on vesting that lapse with the passage of time, together with provisions that unvested options are forfeited when an employee leaves. The retention incentives created by employee options are highest when the stock price is already well above the exercise price of the options and when the employee must remain in the job before being able to exercise the option. Retention incentives are lowest when options are "underwater" and essentially valueless, especially when alternative employers are willing to make a new grant of more-valuable options.

Options clearly provide retention incentives, but do they do so in the most efficient manner? Retention incentives can be created by any compensation mechanism that makes it worthwhile for employees to stay with their current employer rather than to accept an outside offer. For example, retention incentives can be provided by deferred compensation or pensions that depend on remaining with the firm, or by paying employees less than their marginal product early in their career but more later (Lazear, 1979). Alternatively, firms can offer explicit "retention bonuses" to critical employees staying a specified period of time; indeed, such retention bonuses are quite common in situations where a firm is in financial distress. Since risk-averse employees value cash more than options, it seems plausible that explicit cash retention bonuses are a more cost-effective method than options of inducing continued employment.

In addition, it is not obvious to us that retention incentives should optimally vary with company stock prices. Suppose, for example, that all firms in an industry offer identical compensation packages consisting of a base salary and an option grant with an exercise price equal to the grant-date market price. In a bull market, stock prices rise above the exercise 
price of the options and all workers will find it advantageous to stay with their current employers. But, in a bear market, stock prices fall below the exercise prices and workers will rationally leave their current firm to join a competitor offering a fresh compensation package. This latter scenario is currently plaguing much of Corporate America, where option-based retention incentives have evaporated along with shareholder returns.

\section{Motivation?}

The potential motivational benefits of tying top-executive pay to the performance of company stock are clear enough. But, given that 90 percent of stock options are granted below the top-executive level, the relevant question is: are options an efficient way of providing incentives for lower-level managers and employees?

Conceptually, it seems implausible that stock options provide meaningful incentives to lower-level employees. Although employees may hold a substantial fraction of their wealth in a firm (both through firm-specific human capital and through stock in 401(k) plans), they can be granted at most a trivial fraction of the outstanding shares. Thus, a free-rider problem exists: even if employees can increase the value of the firm, their share of that gain through their option holdings is very small. Combining this enormous free-rider problem with the risk imposed on employees through stock-based pay, it seems obvious that cash-based incentive plans based on objective or subjective performance measures can provide stronger and more efficient pay-performance incentives. (See Oyer and Schaefer, 2002, for a detailed analysis of this assertion.)

Tying employee pay to company stock-price performance may provide indirect incentive benefits to the company. For example, stock-based pay may help communicate the 
corporate objective of maximizing shareholder wealth, increase employee morale and encourage workers to engage in mutual monitoring. Although we are unaware of compelling empirical research that supports these claims, we note that these benefits (if they exist) have surely backfired in the current bear market, as mutual-monitoring incentives and the morale of option-holders have plummeted along with stock prices.

\section{Are Traditional Options Efficient For Top Executives?}

Although options are clearly an inefficient way of attracting, retaining and motivating lower-level employees, the case for options for top executives is more compelling. For example, options may help attract entrepreneurial managers and also provide top managers with incentives to take actions that increase the stock price. But even for top managers, there are good reasons to question whether the "traditional stock option" - that is, a ten-year option with relatively short vesting and an exercise price equal to the grant-date market price-represents the most efficient way to provide stock-based incentives.

Many economists embrace the idea that option exercise prices should be "indexed" to the market (for example, Rappaport, 1999). Since executives holding indexed options are rewarded only to the extent that their performance exceeds the market, these plans utilize a less-noisy performance measure, protect executives from market shocks and also protect shareholders from rewarding poorly performing executives in bull markets. In spite of these advantages, indexed options are virtually nonexistent.

We believe the nonexistence of indexed options reflects two factors. First, as discussed further in the next section, grants of indexed options must be expensed in accounting statements (resulting in smaller reported income), while traditional options are not expensed. 
Second, traditional options are much more likely than indexed options to end up with a stock price that exceeds the exercise price. For example, the probability that a traditional option is in the money after ten years is approximately 80 percent. $^{5}$ In contrast, the probability that an indexed option is in the money after ten years is significantly less than 50 percent, because stock returns are skewed to the right (since the minimum return is minus 100 percent but the maximum return is unbounded), and therefore less than half of the firms in an index will have returns that exceed the average. Thus, indexing reduces the company's cost of granting an option, but it reduces the executive's value even more because risk-averse executives attach very low values to options likely to expire worthless. Therefore, to deliver the same value to the executive, it costs the company more to grant indexed options rather than traditional options.

Our argument runs counter to the conventional wisdom, which often asserts that options where the exercise price is indexed to market must be a Pareto improvement to traditional options both for firms and for risk-averse employees. However, in an analysis of indexed options based on our Hall-Murphy (2002) methodology, we find that indexed options dominate traditional options only if the indexed options are granted with exercise prices that are well below market value at time of grant, to offset the major disadvantage of reduced payout probabilities.

More generally, options that are likely to expire worthless provide weak incentives for risk-averse executives since the incentive-value of options is related to how the executive's value changes with incremental increases in the stock price. This is why "premium

5 This estimate is based on the capital-asset pricing model assuming no dividends, expected appreciation of 12.5 percent, and volatility of 30 percent. 
options"- which have an exercise price above the current stock price and are advocated by many shareholder activists who desire to create tougher performance standards for top executives - are poor incentive devices. Increasing the exercise price above the grant-date market price saves the company some money, but it also reduces the marginal value of a change in the stock price to the executive since premium options are more likely to expire underwater. Indeed, with premium options, even significant increases in the stock price may bring little value to the executive, resulting in weaker incentives per dollar spent on compensation by the firm.

In Hall and Murphy (2002), we find that incentives per dollar spent on compensation to risk-averse executives are maximized by granting options with exercise prices that are below, not above, the market price at the grant date. ${ }^{6}$ This ensures that the executive faces an immediate marginal change in wealth for both rises and falls in the stock price. In one situation-namely, when the company offers additional stock-based compensation and simultaneously reduces cash compensation to leave the initial expected utility of the executive unchanged - we find that incentives are maximized through grants of nontradable restricted stock rather than options.

Restricted stock has several advantages over stock options in providing incentives to top executives. Requiring top executives to hold company stock provides relatively stable incentives regardless of the stock price, whereas with stock options the incentive value of options depends on the market price of the stock relative to the exercise price. In particular, options where the market price is well above the exercise price provide incentives similar to 
those provided by stock holdings, but options lose incentive value (and retention value) once the stock price falls sufficiently below the exercise price that the executive perceives little chance that they will ever provide a significant payoff. Option-granting companies with "underwater options" are under constant pressure to lower the exercise price on outstanding options or to grant additional options to effectively replace the underwater ones (see, for example, Hall and Knox, 2002). The difficult pressures resulting from the underwateroptions problem are avoided by granting restricted stock.

Granting restricted stock rather than options also affects managerial incentives to engage in risky investments. An executive holding out-of-the-money options, where the exercise price is above the current market price, will have incentives to undertake riskier investments than will an executive holding in-the-money options; in contrast, investment incentives are roughly independent of stock prices for executive holding stock (unless the price is sufficiently low that the risk from bad outcomes is shifted to debtholders). ${ }^{7}$ In addition, executives holding restricted stock rather than options have better incentives to pursue an appropriate dividend policy. Since options reward only stock-price appreciation and not total shareholder returns (which include dividends), executives holding options have strong incentives to avoid dividends and to favor share repurchases-and several studies have found evidence that managers have responded to this incentive (for example, Lambert, Lanen and Larcker, 1989; Lewellen, Loderer and Martin, 1987; Jolls, 2002; Fenn and Liang,

$6 \quad$ The degree of risk aversion matters here. For risk-neutral executives, for example, incentives per dollar of compensation are maximized by granting an infinite number of options at an infinite exercise price (Hall and Murphy, 2000).

7 Hirshleifer and Suh (1992) argue that option plans (or other plans with "convex" payouts) help mitigate the effects of executive risk aversion by giving managers incentives to adopt rather than avoid risky projects. However, it is not obvious why the optimal "mitigation" should depend on whether options are in or out of the money. 
2002). ${ }^{8}$

Finally, we note that no performance measure, including the stock price, represents a perfect measure of firm value. The advantages of tying executive compensation to the stockprice rather than to accounting returns are premised on the assumption that stock prices incorporate most or all publicly available information and managers cannot take advantage of "too much" private information. In the recent accounting scandals, some executives allegedly boosted stock prices by reporting fraudulently high earnings. Financial market inefficiencies - in this case, private information that accounting data were misleading — not only reduce the effectiveness of stock-based incentives, but also provide incentives to top managers to exploit these inefficiencies, gaming stock-based pay in the same way that they sometimes game accounting-based bonuses. This outcome is somewhat ironic since stockbased pay was, in part, put forward as a solution to the gaming of pay plans based on accounting measures - providing evidence once again that incentives can sometimes have the problem of motivating too well, rather than too little. Although the gaming of stockbased pay became more prevalent in the waning years of the bull market of the 1990s as executives struggled to meet unrealistic shareholder expectations, ${ }^{9}$ we believe that the discipline of investors makes stock-based pay generally less vulnerable to gaming than pay based on highly manipulable accounting measures.

8 A small number of companies offer "dividend protection" for employee stock options, usually accomplished by paying the employee accumulated dividends (plus interest) upon exercise of the underlying options. Although this practice is rare, we expect it will increase if personal income taxes on dividends are reduced.

9 Jensen and Fuller (2002) argue that overpriced equity during the bull market had large "agency costs," motivating managers to make value-destroying (and sometimes unethical and/or illegal) decisions in order to meet the unreasonable expectations of investors. 


\section{So Why Do Companies Really Grant Stock Options?}

"Properly designed" stock-based compensation plans are (by definition) an efficient way of tying pay to corporate performance. However, our analysis reveals problems in the design of top-executive options, and suggests that options are a highly inefficient way of attracting, retaining and motivating lower-level employees. If these conclusions are right, then why, really, do companies grant options, especially to lower-level employees? Moreover, what explains the trends in option grants over the last decade?

In this section, we discuss several possible explanations for the recent escalation in the granting of stock options, including changes in corporate governance, reporting requirements, taxes, the bull market and managerial rent-seeking. These explanations are not mutually exclusive, and all may have contributed to increased grants for top executives (although we are most skeptical of the rent-seeking explanation). However, none of these factors provide a satisfactory explanation for the escalation in broad-based grants to lowerlevel employees. Thus, we offer an alternative hypothesis that we believe explains why companies grant so many options to so many people: boards and managers are convinced that stock options are cheap to grant because there is no accounting cost and no cash outlay, and granting decisions are based on this inaccurate "perceived cost" rather than the muchhigher economic cost of options.

\section{A New Emphasis on Shareholder Value}

If option grants were largely limited to top executives, we believe the escalation could be explained in part by a renewed emphasis on shareholder value reflected by dramatic changes in corporate governance (Holmstrom and Kaplan, 2001). By the early 1990s, 
shareholder groups like the United Shareholders Association, the Council of Institutional Investors and several large state pension funds had become critical of existing executive pay practices that were largely independent of company performance. These concerns were amplified by academic research (especially Jensen and Murphy, 1990a,b) showing that chief executive officers of large companies received small rewards for superior performance and even smaller penalties for failures. Companies responded to these pressures by granting more stock options to their executives. However, in part because risk-averse executives place low values on options, these grants largely came without reductions in any other form of pay, leading to a significant increase in the overall level of executive compensation.

Contemporaneous changes in disclosure and tax rules reinforced stronger linkages between stock performance and executive pay. In late 1992, the Securities and Exchange Commission (SEC) issued new disclosure rules that required company compensation committees to describe company pay practices and justify in detail how they determined the pay of the chief executive officer, and also required companies to prepare a chart showing the company's five-year shareholder returns compared to the market and an industry peer group. Although the new rules made option grants significantly more transparent-which would lead companies to grant fewer options to the extent that options are used to "hide" compensation-we believe that the rules on net encouraged increased grants. The shareholder-returns chart endorsed the idea that the company's primary objective is to create shareholder value, and pay for a top executive is more easily justified if it is demonstrably tied to company performance. Moreover, in the primary compensation table that summarizes payments to the top five executives, only the number rather than the value of options is reported. In contrast, the value of restricted stock grants is reported, and therefore restricted 
stock is naturally added to other pay components to derive "total compensation."

In 1994, the new tax rule disallowing deductions for "non-performance-based" compensation in excess of $\$ 1$ million became effective. Research testing whether the new rule can explain the increase in option pay has been inconclusive (for example, Rose and Wolfram, 2002; Hall and Liebman, 2000; Perry and Zenner, 2001). We are skeptical of this explanation because the explosion in grants of stock options was already underway in the 1980s (Hall and Liebman, 1998; Murphy, 1999), and because the law only applies to the topfive executives who in turn account for only about ten percent of all option grants. However, the new rule constituted an implicit government "blessing" of stock options as appropriate performance-based pay, and this implicit endorsement may have further fueled the escalation in options. 
Figure 2

Dow Jones Industrial Average and the Ratio of Average CEO Pay to Average Pay for Production Workers, 1970-2002

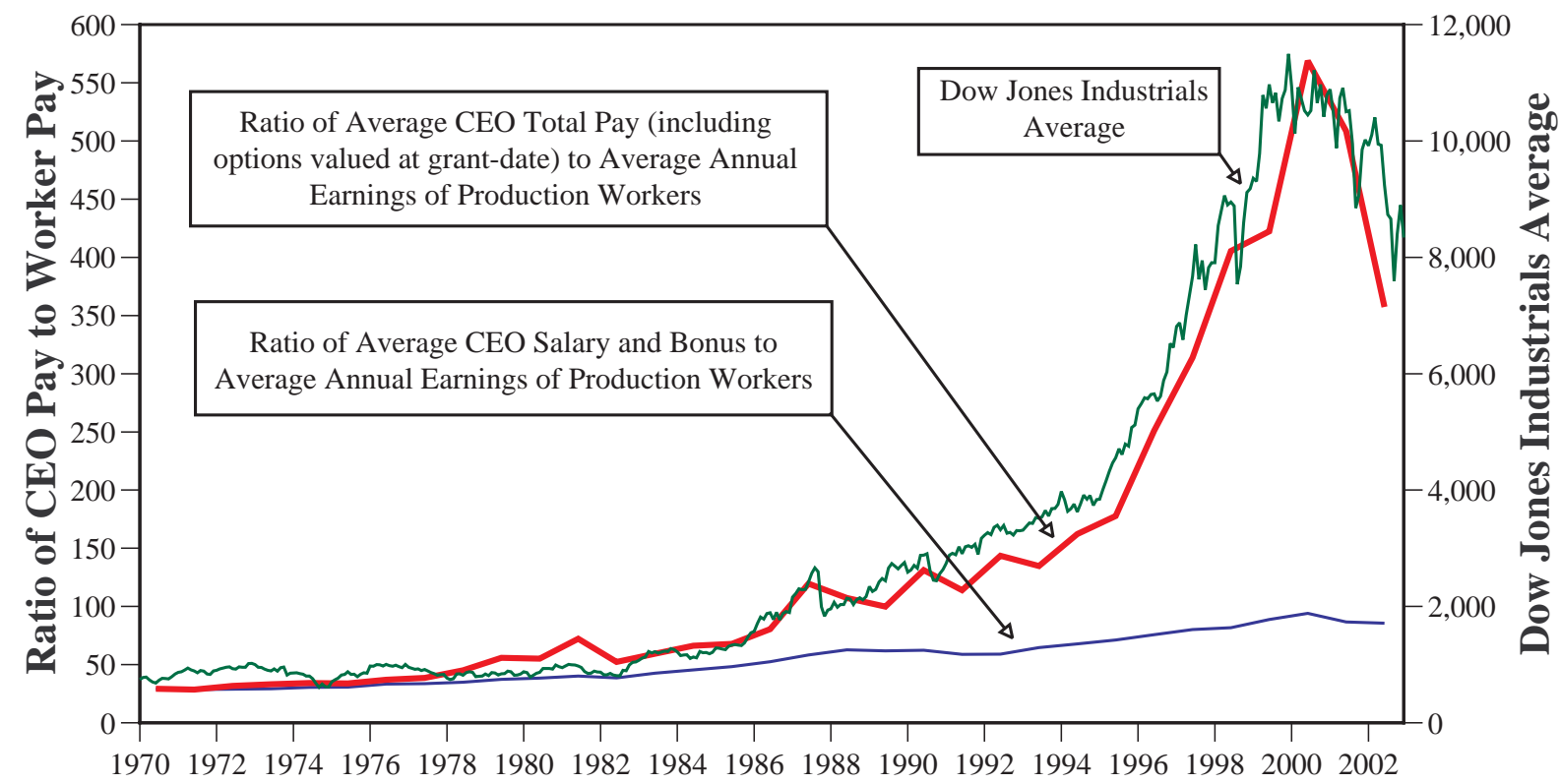

Note: Dow Jones Industrials based on monthly closing averages. CEO sample is based on all CEOs included in the S\&P 500, using data from Forbes and ExecuComp. CEO total pay includes cash pay, restricted stock, payouts from longterm pay programs and the value of stock options granted using ExecuComp's modified Black-Scholes approach. (Total pay prior to 1978 excludes option grants, while total pay between 1978 and 1991 is computed using the amounts realized from exercising stock options during the year, rather than grant-date values.) Worker pay represents 52 times the average weekly hours of production workers multiplied by the average hourly earnings, based on data from the Current Employment Statistics, Bureau of Labor Statistics.

\section{The Bull Market}

The trend in option grants over the past three decades has closely tracked general stock-market indices. Figure 2 documents the correlation between the Dow Jones Industrial Average and the ratio of the pay of the CEO to the average worker between 1970 and 2002. In 1970, the average CEO of a S\&P 500 firm made about 30 times the pay of the average production worker. By 2002, the average S\&P 500 CEO received cash compensation nearly 90 times greater than the average earnings for production workers, and total compensation (defined as cash compensation plus the grant-date value of stock options) of over 360 times the earnings for production workers (down from a peak of 570 in 2000). Most importantly 
for present purposes, CEO cash compensation is weakly correlated with the Dow Jones Average but CEO total compensation is strongly correlated with the stock market. ${ }^{10}$ There are several reasons to expect that the correlation is more than coincidental.First, as stock prices increased sharply during the 1990s, many executives and employees holding options and stock became wealthy. As stories of the riches gained by option holders spread through the media and word-of-mouth, an option frenzy grew. Second, options may indeed have worked: corporate boards and top managers began to associate option grants with successful company performance, especially during the high-tech and internet boom of the late 1990s. Indeed, the increase in options coupled with the renewed focus on shareholder value creation may help explain the overall growth in stock market since the early 1990s. Empirical evidence directly linking option grants to subsequent company performance has been largely inconclusive, however, reflecting the inherent difficulty of conducting convincing tests of the issue. For example, if financial markets are efficient, we would not expect high-option companies to realize systematically higher shareholder returns than those realized by lowoption companies. In addition, even ignoring market efficiency, increasing option grants would lead to improved performance only if "too few" options were awarded initially. Designing and testing the right experiment on how option grants affect firm performance remains the most important research opportunity in the area.

Third, companies are often reluctant to decrease the number of options granted after the stock price increases; indeed, many companies have explicit policies where the grant size

10 The total compensation data in Figure 3 prior to 1992 are based on amounts realized from exercising options, but options were relatively unimportant during this period and average amounts realized during the year were closely correlated with average amounts granted. From 1992 forward the total compensation data are based on grant-date option values using Black-Scholes values, and there is no mechanical reason why options would increase with the market. 
(measured in number of shares rather than dollars) remains constant over time. Since the value of an option increases with the price of the underlying stock, granting a constant number of options will lead to a higher value being granted. Even companies without "fixed share" policies will be affected, since the value of fixed-share grants are included in benchmarking surveys used by compensation-consulting firms. The net result is a ratcheting of the value of option grants during an escalating stock market, and a fall in the value of grants in a declining market.

\section{Managerial Rent-Seeking}

The escalation in executive pay, largely driven by options, may reflect inefficient transfers of wealth from shareholders to greedy executives. This view has been espoused by Bebchuk, Fried and Walker (2002; see also Bebchuk and Fried in this issue), who argue that the escalation in executive stock options reflects the actions of incumbent executives who can raise their own pay by exercising influence over hand-picked directors. Rent-seeking executives increase their pay through options rather than cash in an attempt to camouflage pay to mitigate external scrutiny and criticism. Bebchuk, Fried and Walker argue that rent extraction can explain both trends in pay levels and several features of option plans, including why exercise prices are set at grant-date market prices and are not indexed to general market movements, why options are often reset following market declines, and why firms allow executives to exercise early and diversify (or otherwise hedge the risk of their option and stock holdings).

We are sympathetic to the view that executive pay decisions are typically not made by truly independent boards in truly arms-length negotiations. However, we do not believe that 
rent extraction provides a compelling explanation for the escalation in stock options (and the consequent increase in pay of CEOs), for several reasons.

First, by virtually all accounts, corporate boards have become more rather than less independent over the past decade. Board sizes have declined, and the fraction of outside relative to inside board members has increased (Holmstrom and Kaplan, 2001). Most companies now have compensation committees comprised of two or more independent outside directors; in earlier years the CEO and other insiders often sat on the compensation committee (if the company even had a separate compensation committee). Although corporate governance can surely improve further, changes over the last decade have strengthened board governance and seem inconsistent with an increased ability of executives to extract rents from captive boards.

Second, the managerial rent-extraction hypothesis applies to incumbent executives, and not to executives hired from outside the firm who are more likely to be hired in arms-length transactions. But executives changing companies during the 1990s received large pay increases, indicating that alleged "rents" were transferable - which suggests they are not rents at all (Fee and Hadlock, 2003; Murphy, 2002). Indeed, the existence of outside succession is largely inconsistent with the rent-extraction view, because systematic rents above competitive pay levels will make executives less likely to leave voluntarily, and make attracting executives from other firms more expensive. But, as documented by Murphy and Zábojník (2003), companies in the 1990s (when rent-extraction was supposedly high) were much more likely to hire chief executive officers from outside the company than in the 1980s or 1970s. 
Third, risk-averse and undiversified executives prefer cash over options of equal value to the company. However, the managerial-power hypothesis holds that rent-seeking executives will choose options over cash because options are less transparent to shareholders, politicians, the media or others who would criticize high cash payments. However, the SEC disclosure rules introduced in 1992 were focused in large part on providing better details on stock-option compensation, thus making it harder for top executives to camouflage compensation by granting options. Although we agree that the cost of options is less transparent to shareholders than cash pay, the fact that option compensation became much more transparent during the 1990s - and that grants continued unabated following better disclosure-contradicts the claim that rent-seeking combined with camouflage explains the option explosion.

The managerial rent-extraction hypothesis is, at best, an explanation for the very top executives. As we have emphasized in this article, the escalation in stock options has not been a CEO-specific phenomena: in 2002, for example, more than 90 percent of options granted in the S\&P 500 went to executives and employees below the top five. A compelling explanation for the escalation in stock option grants must be consistent with the increased use of options throughout the company.

\section{The Perceived-Cost Hypothesis}

An alternative explanation for the growth of option-granting in the 1990s is that decisions over options are made based on the "perceived cost" of options rather than on their economic cost (Murphy, 2002). When a company grants an option to an employee, it bears an economic cost equal to what an outside investor would pay for the option. But it bears no 
accounting charge and incurs no outlay of cash. Moreover, when the option is exercised, the company (usually) issues a new share to the executive, and receives a tax deduction for the spread between the stock price and the exercise price. These factors make the "perceived cost" of an option much lower than the economic cost.

The result of making decisions based on perceived rather than economic costs is that too many options will be granted to too many people, and options with favorable accounting treatment will be preferred to (perhaps better) incentive plans with less favorable accounting. From an economic-cost standpoint, options may be an inefficient way to convey compensation and to attract, retain and motivate employees. But from a perceived-cost standpoint, options may seem an efficient way to achieve these objectives.

In many respects, the perceived-cost view of options is analogous to the motivation for the Economic Value Added (EVA) approach (Stern, Stewart and Chew, 1995). EVA is defined as operating profit after a charge for the capital required to earn that profit. The key idea behind EVA is that managers perceive the cost of equity capital to be small, and make decisions based on this erroneous perceived cost rather than on the much higher economic cost. Basing pay on EVA forces managers to recognize the cost of equity capital, leading to better decisions and a more efficient use of capital.

The perception that options are nearly free to grant is readily acknowledged by practitioners and compensation consultants, but is usually dismissed by economists because it implies systematic suboptimal decision-making and a fixation on accounting numbers that defies economic logic. But managers often respond to accounting concerns in ways that seem irrational to economists. For example, when FASB imposed a current accounting charge for 
anticipated post-retirement health-care liabilities beginning in 1993, managers predicted that stock prices would fall with reported income. Stock prices did not fall because markets are reasonably efficient and the economic liability was already incorporated in stock prices (Amir, 1993; Espahbodi, Strock and Tehranian, 1991), but companies nonetheless made dramatic cutbacks in the medical benefits for retirees (Mittelstaedt, Nichols and Regier, 1995). The new accounting rule apparently increased the perceived cost of these benefits, putting them more in line with their actual economic cost, and as a result the company reduced the level of the benefits.

The disappearance of option repricing also illustrates how companies respond to accounting rules that have no affect on company cash flows. This common, but controversial, practice virtually disappeared after December 1998, when FASB imposed an accounting charge for repriced options (see Murphy, 2003, and Carter and Lynch, 2003). Many companies with declining stock prices circumvented the accounting charge on repriced options by canceling existing options and re-issuing an equal number of options after waiting six months or more (Zheng, 2003). But this replacement is not neutral. It imposes substantial risk on risk-averse employees since the exercise price is not known for six months and can conceivably be above the original exercise price. In addition, canceling and reissuing stock options in this way provides perverse incentives to keep the stock-price down for six months so that the new options will have a low exercise price. All of this scrambling to avoid an accounting charge!

From the perspective of many boards and top executives who perceive options to be nearly costless, the relevant "cost" of options in practice is the trouble associated with 
obtaining shareholder approval for additional grants coupled with the cost of additional dilution. Advisory firms often base their shareholder voting recommendations primarily on the option "overhang" (that is, the number of options granted plus options remaining to be granted as a percent of total shares outstanding), and not on the economic cost of the proposed plan. In addition, the number of options granted is included in fully diluted shares outstanding and therefore increased grants will decrease fully diluted earnings per share. These perceived costs vary with the number of options granted, and not with the dollar-value of the grants.

We believe that the perceived-cost view of options explains why options are granted in such large quantities to large numbers of workers, and also explains why grant-date values rose dramatically and subsequently declined with the stock market (see Figures 1 and 2). We speculate that as grants for top executives increased (for reasons offered above), companies faced growing pressure to push grants down throughout the organization (see, for example, Flanigan, 1996). Employees clamored for broad-based grants, as long as other components of their compensation were not lowered. Boards readily succumbed, since (prior to changes in exchange listing requirements in mid-2003) shareholder approval was required for plans concentrated among top executives but was not required for broad-based plans. In addition, several bills that encouraged broad-based stock option plans were introduced in Congress. ${ }^{11}$ As a result of these pressures, the number of options granted (expressed as a fraction of

11 For example, H.R. 5242 "To amend the Internal Revenue Code of 1986 to encourage the granting of employee stock options" (introduced July 2002; currently in committee); S. 2877 "To amend the Internal Revenue Code of 1986 to ensure that stock options are granted to rank-and-file employees as well as officers and directors" (introduced August 2002; in committee); and H.R. 2788 "To amend the Internal Revenue Code of 1986 to promote the grant of incentive stock options to non-highly compensated employees" (introduced October 1997; in committee). 
outstanding shares) grew modestly (see Panel A of Table 1). But, the economic cost of these grants followed general stock-market movements, growing dramatically through 2000.

\section{The Case for Expensing Stock Options}

The recent accounting scandals have renewed a heated public debate on the accounting treatment of options. In March 2003, FASB announced it would consider mandating an accounting expense for options, hoping for a final rule by early 2004 . Proposals that stock options must be recorded as an expense - in the jargon, that options be "expensed"- have been endorsed by FASB's international counterpart (the International Accounting Standard Board) and also by Alan Greenspan, Warren Buffett and a growing number of business journalists and academics. Opposition has come from the Bush Administration, the Business Roundtable, TechNet (the nation's largest high-tech trade association), the National Association of Manufacturers, the U.S. Chamber of Commerce and the International Employee Stock Options Coalition (an industry group created explicitly to oppose an accounting charge). Congress has been divided on the issue. ${ }^{12}$

Imposing an accounting charge on stock options would not affect current or future cash flow, but parties on both sides of the debate agree that such a change would result in granting fewer options, especially to rank-and-file workers. One common argument for why fewer options would be granted is that companies fear a backlash in the stock market if investors understood the true cost of the options. But this explanation - that investors do not currently

12 For example, in 2003 Senators McCain and Levin reintroduced a bill that would disallow corporations from deducting option costs from taxable profits unless companies also expensed their options on their income statements. However, 15 other senators (including Senators Kennedy and Lieberman) have opposed mandatory option expensing, arguing that it would inflict a "fatal blow" on broad-based option plans. In March 2003, the "Broad-Based Stock Option Transparency Act" was introduced in the House; this bill would forbid FASB from imposing an accounting charge on options for at least three years. 
understand the cost of options - has been studied and rejected by most academic research (see, for example, Aboody, 1996, and Aboody, Barth and Kasznik, 2001). Current accounting rules require companies to disclose the value of options granted in a detailed footnote to company accounting statements. Several studies have shown that the costs of options are indeed reflected in stock prices, which suggest that increasing disclosure by making it more detailed and more frequent is unlikely to affect practice.

However, the fact that financial markets see through the "veil of accounting" does not imply that accounting considerations are irrelevant, since accounting rules affect-and sometimes distort-managerial decisions. As we have argued, part of the reason that managers and boards have been so willing to grant options is that they are making decisions based on the artificially low perceived cost of options rather than on their economic cost. This insight provides a strong case for a requirement that options be expensed. The overall effect of bringing the perceived costs of options more in line with economic costs will be that fewer options will be granted to fewer people: stock options are likely to be reduced and concentrated among those executives and key technical employees who can plausibly affect company stock prices.

In addition, we predict that expensing will lead to compensation decisions that are better designed to attract, retain and motivate a productive workforce. For example, current accounting rules create a bias in favor of stock options and against other types of stock-based compensation plans, including restricted stock, options where the exercise price is set below the current market value, options where the exercise price is indexed to industry or market performance and performance-based options that vest only if key performance thresholds are 
achieved. Also, current rules are biased against cash incentive plans that can be tied in creative ways to increases in shareholder wealth. As long as stock options appear to be "free" relative to sensible alternatives that trigger accounting charges, these alternatives will rarely receive appropriate consideration.

The root of the trouble with options, we believe, is that decisions to grant such options are based on a perceived cost of options that is substantially lower than the economic cost. Mitigating perceived-cost problems involves both educating managers and boards on the true economic costs of stock options and eliminating the asymmetries between the accounting and tax treatment of stock options and other forms of compensation. Proposals to impose an accounting charge for option grants will close the gap between perceived and economic costs and are a step in the right direction. 


\section{References}

Aboody, David. 1996. "Market Valuation of Employee Stock Options." Journal of Accounting and Economics. 22, pp. 357-391.

Aboody, David, Mary E. Barth and Ron Kasznik. 2001. "SFAS 123 Stock-Based Compensation Expense and Equity Market Values." Working paper.

Amir, Eli. 1993. "The Market Valuation of Accounting Information: The Case of Postretirement benefits other than Pensions." The Accounting Review. 68:4, pp. 703-724.

Bebchuk, Lucian, Jesse Fried, and David Walker. 2002. "Managerial Power and Executive Compensation." University of Chicago Law Review. 69.

Bebchuk, Lucian, and Jesse Fried. 2003. "Executive Compensation as an Agency Problem." Journal of Economic Perspectives. (this issue).

Black, Fisher and Myron Scholes. 1973. "The Pricing of Options and Corporate Liabilities." Journal of Political Economy. 81, pp. 637-59.

Carter, Mary Ellen and Luann J. Lynch. 2003. "The Consequences of FASB's 1998 Proposal for Stock Option Repricing." Journal of Accounting and Economics (forthcoming).

Cassidy, John. 2002. “The Greed Cycle.” The New Yorker. September 23.

Core, John and Wayne Guay. 2001. "Stock Option Plans for Non-Executive Employees." Journal of Financial Economics. 61:2, pp. 253-287.

Espahbodi, Hassan, Elizabeth Strock and Hassan Tehranian. 1991. "Impact on Equity Prices of Pronouncements Related to Nonpension Postretirement Benefits." Journal of Accounting and Economics. 14, pp. 323-346.

Fee, Edward and Charles Hadlock. 2003. "Raids, Rewards and Reputations in the Market for CEO Talent.” Review of Financial Economics. (Forthcoming).

Fenn, George and Nellie Liang. 2001. "Corporate Payout Policy and Managerial Stock Incentives.” Journal of Financial Economics. 60, pp. 45-72.

Flanigan, James. 1996. "It's Time For All Employees To Get Stock Options." Los Angeles Times. April 21.

Hall, Brian J. and Jeffrey B. Liebman. 1998. "Are CEOs Really Paid Like Bureaucrats?" Quarterly Journal of Economics. 113, August, pp. 653-691. 
Hall, Brian J. and Jeffrey B. Liebman. 2000. "The Taxation of Executive Compensation." in Tax Policy and the Economy, NBER volume edited by James Poterba, MIT Press, Vol. 14.

Hall, Brian J. and Kevin J. Murphy. 2000. "Optimal Exercise Prices for Risk Averse Executives.” American Economic Review. May, pp. 209-214.

Hall, Brian J. and Kevin J. Murphy. 2002. "Stock Options for Undiversified Executives," Journal of Accounting and Economics. 33, pp. 3-42.

Hall, Brian J. and Thomas A. Knox. 2002. "Managing Option Fragility.” NBER Working Paper 9059, July.

Hirshleifer, David and Y. Suh. 1992. "Risk, Managerial Effort, and Project Choice." Journal of Financial Intermediation. 2, pp. 308-345

Holmstrom, Bengt and Steven Kaplan. 2001. "Corporate Governance and Takeovers in the U.S.: Making Sense of the 80s and 90s." Journal of Economic Perspectives. Spring, pp. 121-144.

Ittner, Christopher D., Richard A. Lambert, and David F. Larcker. 2003. "The Structure and Performance Consequences of Equity Grants to Employees of New Economy Firms." Journal of Accounting and Economics. 34, pp. 89-127.

Jensen, Michael C. and Kevin J. Murphy. 1990a. "Performance Pay and TopManagement Incentives.” Journal of Political Economy. 98:2, pp. 225-64.

Jensen, Michael C. and Kevin J. Murphy. 1990b. "It's Not How Much You Pay, but How." Harvard Business Review. May.

Jensen, Michael C. and Joseph Fuller. 2002. "Just Say No To Wall Street: Putting a Stop to the Earnings Game." Journal of Applied Corporate Finance. 14, pp. 41-46.

Jolls, Christine. 2002. "Stock Repurchases and Incentive Compensation." Working paper.

Lambert, Richard A., William Lanen, and David F. Larcker. 1989. "Executive Stock Option Plans and Corporate Dividend Policy." Journal of Financial and Quantitative Analysis. 24:4, pp. 409-425.

Lambert, Richard A., David F. Larcker, F. and Robert E. Verrecchia. 1991. "Portfolio Considerations in Valuing Executive Compensation." Journal of Accounting Research. 29:1, pp. 129-49.

Lazear, Edward P. 1979. "Why Is There Mandatory Retirement?" Journal of Political Economy. 87, December, pp. 1261-1264. 
Lewellen, Wilbur, Claudio Loderer and Kenneth Martin. 1987. "Executive Compensation and Executive Incentive Problems: An Empirical Analysis." Journal of Accounting and Economics. 9, pp. 287-310.

Madrick, Jeff. 2003. “A Theory of Corporate Greed.” New York Times. February 20.

Meulbroek, Lisa K. 2001. "The Efficiency of Equity-Linked Compensation: Understanding the Full Cost of Awarding Executive Stock Options." Financial Management 30, pp. 5-30.

Mittelstaedt, Fred, William Nichols and Philip Regier. 1995. "SFAS No.106 and Benefit Reductions in Employer-Sponsored Retiree Health Care Plans." The Accounting Review. 70:4, pp 535-556.

Murphy, Kevin J. 1999. "Executive Compensation," in Orley Ashenfelter and David Card, eds., Handbook of Labor Economics, Vol. III, North Holland.

Murphy, Kevin J. 2002. "Explaining Executive Compensation: Managerial Power versus the Perceived Cost of Stock Options." University of Chicago Law Review. Summer, 69:3, pp. 847-869.

Murphy, Kevin J. 2003. "Stock-Based Pay in New Economy Firms," Journal of Accounting and Economics. 34, pp. 129-147.

Murphy, Kevin J. and Jan Zábojník. 2003. "Managerial Capital and the Market for CEOs." Unpublished manuscript.

Oyer, Paul and Scott Schaefer. 2002. "Why Do Some Firms Give Stock Options to All Employees?: An Empirical Examination of Alternative Theories." Working Paper.

Perry, Tod and Marc Zenner. 2001. "Pay for Performance? Government Regulation and the Structure of Compensation Contracts." Journal of Financial Economics. 62:3, pp. 453488 .

Rappaport, Alfred. 1999. "New Thinking on How to Link Executive Pay with Performance." Harvard Business Review. March/April, pp. 91-101.

Rose, Nancy L. and Catherine Wolfram. 2002. "Regulating Executive Pay: Using the Tax Code to Influence Chief Executive Officer Compensation." Journal of Labor Economics. April, 20, pp. 138-175.

Schizer, David M. 2000. "Executives and Hedging: The Fragile Legal Foundations of Incentive Compatibility." Columbia Law Review. 100, pp. 440-468.

Stern, Joel M., G. Bennett Stewart and Donald H. Chew. 1995. "The EVA Financial Management System." The Journal of Applied Corporate Finance. 8:3. 
Zheng, Liu. 2003. "Six-Month-One-Day Option Exchange: The Impact of the Accounting Rule on Stock Option Repricing." Unpublished manuscript, University of Southern California. 